\title{
A nagyobb méretü géndeletiók jelentősége a sclerosis tuberosa diagnosztikájában: az első magyar esetek bemutatása
}

\author{
Kövesdi Erzsébet dr. ${ }^{1,2}$ - Bene Judit dr. ${ }^{1,2}$ - Nagy Nikoletta dr. ${ }^{3}$ \\ Horváth Ágnes dr. ${ }^{4}$. Melegh Béla dr. ${ }^{1,2}$. Hadzsiev Kinga dr.. ${ }^{1,2}$ \\ ${ }^{1}$ Pécsi Tudományegyetem, Általános Orvostudományi Kar, Klinikai Központ, Orvosi Genetikai Intézet, Pécs \\ ${ }^{2}$ Pécsi Tudományegyetem, Szentágothai János Kutatóközpont, Pécs \\ ${ }^{3}$ Szegedi Tudományegyetem, Általános Orvostudományi Kar, Orvosi Genetikai Intézet, Szeged \\ ${ }^{4}$ Markusovoszky Egyetemi Oktatókórház, EEG Diagnosztikai és Epilepszia Centrum, Szombathely
}

\section{A szerző́k cikküket a Pécsi Tudományegyetem alapitásának} 650. évfordulójának tiszteletére ajánlják.

\begin{abstract}
A sclerosis tuberosa nagyfokú fenotípusos heterogenitást mutató ritka betegség, jellemző tünete a multiplex hamartomák megjelenése különböző szervekben. Autoszomális domináns öröklődésmenetet mutat, hátterében két génnek, a TSC1-nek, illetve a TSC2-nek a mutációi állnak. Jelen közleményünkben két fiú, illetve két középkorú nőbeteg esetét mutatjuk be, akiknél a TSC1/TSC2 génben Sanger-szekvenálással kóroki eltérést nem tudtunk igazolni, azonban a multiplex ligatiofüggő próba amplifikációjával különböző méretű deletiókat igazoltunk a TSC2 különböző régióiban. Valamennyi beteg hordozza a betegség jellegzetes vezető klinikai tüneteit, azonban az egyéni fenotípusos variabilitásuk rendkívüli módon különbözik. Közleményünkkel a nagyobb méretű géndeletiók relatív gyakori előfordulására hívjuk fel a figyelmet.
\end{abstract}

Orv Hetil. 2017; 158(30): 1188-1194.

Kulcsszavak: sclerosis tuberosa, TSC2, MLPA, deletio

\section{Importance of gross deletions in the diagnosis of tuberous sclerosis complex: the first Hungarian cases}

Tuberous sclerosis complex is a rare disease with high phenotypic heterogeneity, characterized by the appearance of multiplex hamartomas in the different organs. The disease is inherited by autosomal dominant manner, due to the mutations of two genes: the TSC1 or the TSC2. In this publication we present the cases of two young male and two middle-aged female patients, where pathogenetic differences of TSC1/TSC2 could not be verified by Sanger sequencing. However, multiplex ligation-dependent probe amplification confirmed different sizes of deletions in different regions of the TSC2 gene. All patients carry the typical clinical signs of the disease. However, the individual phenotypic variability is very different. With this manuscript, we would like to draw attention to the relative frequent rate of gross gene deletions.

Keywords: tuberous sclerosis, TSC2, MLPA, deletion

Kövesdi E, Bene J, Nagy N, Horváth Á, Melegh B, Hadzsiev K. [Importance of gross deletions in the diagnosis of tuberous sclerosis complex: the first Hungarian cases]. Orv Hetil. 2017; 158(30): 1188-1194.

(Beérkezett: 2017. április 18.; elfogadva: 2017. május 16.) 


\section{Rövidítések}

ADHD = figyelemhiányos hiperaktivitás-zavar; CSF $=$ cerebrospinalis folyadék; $\mathrm{CT}=$ komputertomográfia $; \mathrm{EEG}=$ elektroenkefalográfia; GAP = GTP-áz-aktiváló protein; $\mathrm{MLPA}=$ multiplex ligatio függő próba amplifikáció; $\mathrm{MR}=$ mágneses rezonancia; $\mathrm{mTOR}=$ mammalian target of rapamycin; $\mathrm{SEGA}=$ subependymalis óriássejtes astrocytoma; $\mathrm{SEN}$ = subependymalis nodus; TAND = (tuberous sclerosis-associated neuropsychiatric disorder) sclerosis tuberosához asszociált neuropszichiátriai betegségek; TBC1D7 $=$ TBCl doméncsalád 7-es tag; TS = sclerosis tuberosa; TSCl $=$ tuberous sclerosis protein $1 /$ hamartin; TSC2 $=$ tuberous sclerosis protein $2 /$ tuberin

A sclerosis tuberosa (TS) egy fenotípusosan nagyfokú heterogenitást mutató, autoszomális domináns öröklődésű ritka genetikai betegség [1]. A TS prevalenciája világszerte körülbelül 1:6000-re tehető [2], ami azt jelenti, hogy e betegség tekintetében Magyarországon mintegy 1600 fó lehet érintett. A betegség jellemző tünete a multiplex hamartomák megjelenése különböző szervekben, fóként a bőr, az agy, a szem, a szív, a tüdő, valamint a vesék érintettsége jellemző [3]. A tünetek megjelenése némileg életkori sajátosságokat mutat. A TS diagnózisának felállításához kritériumrendszert dolgoztak ki, amely major, valamint minor tünetek meglétén alapul. A TS diagnózisa biztos kettő major vagy egy major és kettônél több minor kritérium megléte esetében. Lehetséges diagnózisnál elegendő egy major vagy kettőnél több minor kritérium megléte [4].

A tünetek megjelenése rendkívül változatos, még egy családon belül ugyanazt a mutációt hordozva, a családtagok tünetei nagyfokú variabilitást mutatnak: egyes családtagoknál a tünetek enyhék, míg mások súlyosan érintettek [5-7]. Első tünet gyakran az intrauterin észlelt cardialis rhabdomyoma lehet $(60 \%)$, amely szakirodalmi adatok szerint már a terhesség 17 . hetében kimutatható rutin terhességi ultrahangvizsgálat során [8]. Bár a rhabdomyomák nagyrészt tünetmentesek, azonban a későbbiekben gyakran vezethetnek szívritmuszavarhoz vagy Wolf-Parkinson-White-szindrómához. A bőrgyógyászati tünetek korai életkorban már felvethetik a TS gyanúját. Néhány betegnél már megszületést követően észlelhetôek a hipo- vagy hiperpigmentált bőrterületek, míg másoknál csak későbbi évek során, gyermek-, illetve felnőttkorban jelentkeznek a specifikus eltérések [3], amelyek lehetnek jellegzetes alakú hypomelanoticus foltok (90\%), angiofibromák (75\%), köröm körüli fibromák (20\%), shagreen foltok, valamint konfettiszerü bőrlaesiók [4]. Hároméves kortól jelentkezik a betegségre nagyon jellemző, az arcon mutatkozó adenoma sebaceum, Pringlecsomók, gyakran ez a tünet hívja fel a figyelmet a betegségre.

Szintén a gyermekkori tünetek közé tartoznak a központi idegrendszert érintő tünetek, amelyek a TS-betegek jelentôs arányát érintik. Megjelenésük szerint lehetnek subependymalis nodusok (SEN), subependymalis óriássejtes astrocytomák (SEGA), valamint corticalis tuber(ek) [9]. Elhelyezkedésük, valamint növekedésük mértéke fontos klinikai tényező, mivel megakadályozhatják a cerebrospinalis folyadék (CSF) áramlását, ami obstruktív hydrocephalushoz vezethet [10]. Mindezek mellett igen gyakori (90-95\%) a kognitív deficit, az autizmus spektrumzavar, valamint a különböző jellegú epilepsziás rohamok is [3]. Az epilepsziás rohamok az esetek 67\%-ában már igen korán, az élet első 12 hónapja során jelentkeznek [11]. A TS az egyik leggyakoribb oka a súlyos csecsemókori úgynevezett katasztrófaepilepsziának, a West-szindrómának. A rohamok ilyen korai megjelenése magasabb kockázati tényezôt jelent a későbbiekre nézve: súlyosabb fokú rohamok és neurokognitív zavarok kialakulását eredményezheti [12].

A TS-hez társuló neuropszichiátriai rendellenességek, mint az autizmus (40-50\%) és figyelemhiányos hiperaktivitás-zavar (ADHD) $(30-50 \%)$ változatos megjelenési formában és súlyossági fokban fordulnak elő a TS-betegpopulációban $[13,14]$. A TS-hez társuló különböző típusú és súlyosságú viselkedésbeli, intellektuális és pszichoszociális betegségeket jelenleg a „TAND” mozaikszó alatt csoportosítják (sclerosis tuberosához asszociált neuropszihiátriai betegségek - tuberous sclerosis-associated neuropsychiatric disorder) [15]. Főleg fiatal felnőtttkorban jelentkeznek a renalis tünetek, a TS-betegek $80 \%$ ánál angiomyolipomák vagy vesecysták (50\%) alakulnak ki. A vesében kialakult angiomyolipomák nagyra nőhetnek és kifejezetten vérzékenyek. Szintén gyakori velejárója a betegségnek a veserák is [16]. Ugyancsak felnőttkorban észlelhetjük - egyes megfigyelések szerint inkább nőbetegekben - a pulmonalis leiomyomatosist, ami egyes betegekben pneumothorax kialakulásához vezethet. Gyakori a phacomatosist okozó retinalis hamartoma vagy a retinagliosis.

Jelen ismereteink szerint a TS tüneteinek kialakulásában két tumorszuppresszor génben, a TSC1 vagy a TSC2 génben bekövetkező patogén mutáció játszik szerepet. A TSCl gén a hamartin nevú fehérjét kódolja, a 9-es kromoszómán található és 23 exonból áll. A TSC2 gén a tuberint kódolja, a 16-os kromoszómán lokalizálódik és 41 exont tartalmaz $[17,18]$. A hamartin és a tuberin, mint GTP-áz-aktiváló fehérjék (GAP) egymáshoz kötődve egy funkcionális heterodimer komplexet képeznek [19], amely normális körülmények között az mTOR(mammalian target of rapamycin) jelátviteli út szabályozásában játszik fontos gátlószerepet [20]. Az mTORjelátvitel olyan folyamatokat szabályoz, mint a sejtnövekedés, -proliferáció, fehérjeszintézis és -metabolizmus [21]. TSC1/TSC2 génmutáció esetén, az mTOR-jelátviteli út hibás szabályozása miatt, fokozódik a sejtnövekedés, -proliferáció, amely végeredményül tumorok képződését segíti elő [22]. Mivel mind a hamartin, mind a tuberin szükséges a komplex megfelelő múködéséhez, ezért az egyikükben bekövetkező mutáció elegendő a betegség kialakulásához.

Az utóbbi pár év kutatásai alapján egy harmadik komponens, a $\mathrm{TBCl}$ doméncsalád 7-es tagja (TBClD7) is 
kapcsolódik a fent említett komplexhez, amely a hamartinon keresztül a hamartin-tuberin komplexet stabilizálja [23]. Az eddigi szakirodalmi adatok alapján a TBC1D7 gén mutációi intellektuális zavar és megalencephalia kialakulásához vezet a TS fóbb jellegzetes tünetei nélkül [24]. A TS-betegek 70\%-ánál a TSC2 génben bekövetkező mutációk, míg kisebb hányadban a TSC1 gén mutációi $(10 \%)$ tehetők felelőssé a tünetek kialakulásáért. Az esetek egyharmada familiáris, míg kétharmada sporadikus formában fordul elő [25]. Azonban az alapján, hogy melyik génben milyen mutáció alakítja ki a kórképet, pontos fenotípus-genotípus korrelációt nem tudunk felállítani. Egyes megfigyelések szerint azoknál a betegeknél, akiknél a mutáció a TSC2 génben alakult ki, sokkal súlyosabb tüneteket mutatnak azokhoz képest, mint akik TSC1 génmutációt hordoznak [26-28]. Más megfigyelések szerint olyan esetek is ismertek, ahol a TSC1 génmutációk súlyos fenotípusos jegyekkel jártak [28], míg a TSC2 génmutációk csak enyhe tüneteket okoztak [29, 30]. Emiatt a klinikai tünetek alapján nem lehetséges megjósolni előre, hogy egy adott tünetcsoporttal rendelkező beteg esetében mely gén hordozza az adott fenotípus kialakulásáért felelős patogén eltérést [31]. Nagy géndeletio a betegek körülbelül 6-8\%-ában észlelhető, gyakrabban a TSC2 génben detektáljuk és irodalmi adatok alapján sporadikus betegeknél gyakoribb.

Jelen közleményünkben négy magyar beteget mutatunk be, akiknél a TSC1/TSC2 gének hagyományos Sanger-féle szekvenálásával a tünetek hátterében eltérést nem tudtunk igazolni. Ellenben mindegyiküknél multiplex ligatiofüggő próba amplifikációjával (MLPA) különböző méretű deletiókat mutattunk ki a TSC2 génben (1. táblázat).

\section{Módszer}

Intézetünkben 2011 óta történik a TSC1 és TSC2 gén vizsgálata, ez alatt az időszak alatt 86 beteg és családtagjaiknak vizsgálatát végeztük el. A minták egy része intézetünk genetikai tanácsadójából, másik része az ország különböző intézeteiben múködő genetikai tanácsadókból származik. Természetesen a betegek kivizsgálása - ahogy szokásos - minden esetben társszakmák bevonásával történt. A betegek a humángenetikai törvénynek megfelelően genetikai tanácsadásban részesültek, amelynek részeként részletes fenotípus-elemzés történt, emellett írásos beleegyezésüket adták a genetikai vizsgálat elvégzéséhez, valamint adataik tudományos közleményekben történő felhasználásához.

$\mathrm{Az}$ egyes betegek mintáinak molekuláris genetikai vizsgálataihoz EDTA-val alvadásgátolt perifériás vér fehérvérsejtjeiből, rutin kisózásos módszerrel, illetve E.Z.N.A. ${ }^{\circledR}$ Blood DNA Maxiprep Kit-tel (VWR International Kft.) kinyert DNS-mintát használtunk. A TSC2 gén nagyobb átrendeződéseinek vizsgálatához MLPAkit segítségével vizsgáltuk a gyártó MRC Holland (Amszterdam, Hollandia) leírása alapján. A módszer egy vagy több exon, illetve a teljes gén kópiaszám-változásának (deletio/duplikáció) kimutatására alkalmas.

\section{Esetismertetések}

Első, bemutatásra kerülő betegünk egy jelenleg kétéves fiúgyermek, aki a mater II. eseménytelen terhességéből született, a családi anamnézisben negatív. A beteget először 3,5 hónaposan epileptiform görcs miatt vizsgálták, a kivizsgálás során epilepszia diagnózisát állították fel. Jelenleg vigabatrin és nitrazepam mellet egy-egy absence roham észlelhető. Koponya-MR-vizsgálata kiterjedt corticalis tubereket és migrációs sávokat mutatott. A bőrgyógyászati tünetek közül számos foltos hipopigmentáció, valamint az állon egy fibroma észlelhető. Neurológiai státuszában generalizált izomhypotonia mellett megkésett mozgás- és beszédfejlődés detektálható.

Második betegünk egy jelenleg 10 éves fiúgyermek, aki a mater IV. eseménytelen terhességéből született. A családi anamnézis TS tekintetében pozitív; apai nagyapjánál vesecysta, valamint hydrocephalus, fiútestvérénél embrionális rhabdomyosarcoma formájában jelentkezett a kórkép. Ez a fiútestvér nyolcévesen meghalt. Páciensünknél hathetes korban a rutin ultrahangszürésen vesecystát észleltek, amelyek száma folyamatosan növekedett. A bőrgyógyászati tünetek közül a shagreen folt a bal csípólapátja felett már születése óta látható, valamint testszerte hipopigmentált foltok mutatkoznak. Arcán ötéves kora óta adenoma sebaceum látható. A koponya MR-vizsgálata corticalis tubereket mutatott ki, epilepsziája nem volt, az EEG-vizsgálat is az életkorának megfelelő mintázatot mutatott. Neurológiai státuszára részképességzavarok - dyslexia, dysgraphia és dyscalculia - jellemzők.

Harmadik betegünk egy jelenleg 40 éves nő, akit gyermekkora óta bőrgyógyászaton gondoznak adenoma sebaceum miatt. Hasi panaszai miatt korábban hasi és mellkasi CT-vizsgálat történt, amely során a vesében angiomyolipomákat detektáltak, a koponya-MR-vizsgálat corticalis tubereket írt le. Családi anamnézise pozitív: három fiúgyermeke közül a második, ötéves fiúgyermekénél postnatalisan cardialis rhabdomyomát diagnosztizáltak, ezért gyermekkardiológián gondozzák. A legkisebb, jelenleg négyéves fiúgyermeke arcán adenoma sebaceum látható, belszervi kivizsgálás egyelőre nem történt. Az anyai leánytestvér két gyermekénél valószínűsíthető TS: jelenleg 45 éves lánya mentális retardáció miatt intézetben él, 36 éves fiánál mindkét vesében cysták vannak, adenoma sebaceum és hypomelanoticus foltok kíséretében.

Negyedik betegünk, a jelenleg 35 éves nő családi anamnézise negatív. Születése után már észlelték depigmentált foltjait lábain és karján. Ötéves kora után arcán adenoma sebaceum jelentkezett, ami fokozatosan progressziót mutatott. Hatéves korában komplex parciális rohamok miatt elvégzett EEG-vizsgálat felvételei generalizált lassú tüske-hullám mintát mutattak, a CT-vizsgálat 
mindkét féltekében többszörös corticalis, subcorticalis tubereket és subependymalis nodulusokat mutatott, ami igazolta a TS diagnózisát. Rendszeres ellenőrzés, agyi MR-kontrollok során a tuberek számának és nagyságának lassú progresszióját észlelték. Epilepsziás rohamai kezdetben naponta jelentkeztek, kombinált terápia (felbamat, levetiracetam) mellett jelenleg havonta háromnégy alkalommal jelentkező, pár másodperces komplex parciális rohamai vannak. Az EEG-felvételek alapján feltehetően jobb oldali temporalis góc az epilepszia szempontjából aktív góc. Szemfenéki eltérés nincs, a betegség lehetséges szervi manifesztációi közül veseérintettséget találtak, mindkét vesében multiplex angiomyolipomatosis észlelhető, megtartott vesefunkció mellett. Mentális fejlődésben elmaradt, autisztikus magatartást mutat, időnként súlyos magatartászavarral. Epileptológiai és nefrológiai gondozás alatt áll, lassan progrediáló kórképét folyamatos MR-, EEG- és hasi CT-vizsgálatokkal ellenőrzik.

\section{Eredmények}

A betegek MLPA-vizsgálata során mind a négy beteg esetében a TSC2 génben különböző méretű és lokalizációjú deletiókat azonosítottunk heterozigóta formában. A négy bemutatott eset közül az elsóként bemutatott fiúgyermek esetében mutattuk ki a legnagyobb régiót érintő deletiót. Esetében az első 35 exon deletióját azonosítottuk. A második fiúgyermeknél a gén első fele deletio szempontjából nem volt érintett, esetében a gén második kétharmadának, egy 25 exont érintő területének, a 17-41 exonoknak a deletióját mutattuk ki. Az első két beteggel ellentétben a harmadik és a negyedik betegnél, az első két beteghez képest sokkal kisebb régiót érintő deletiót tudtunk detektálni: a harmadik betegnél az 5'UTR, valamint az 1-es, 2 -es exonok, míg a negyedik páciens esetében az 5'UTR és az 1 -es exon deletióját azonosítottuk. Feltételezhetően ezek a deletiók állhatnak az egyes betegeknél leírt tünettan hátterében. A közleményben bemutatott betegek genotípus-fenotípus adatait az 1. táblázatban foglaltuk össze.

\section{Megbeszélés}

A TS hátterében a TSC1/TSC2 komplex különböző mutációi állhatnak. A betegek 70\%-ánál a TSC2 génben bekövetkező mutációk, míg kisebb hányadban a TSCl gén mutációi tehetők felelőssé a tünetek kialakulásáért. TSC2 esetében a nagyobb deletiók és átrendeződések sokkal gyakrabban fordulnak elö, mint a TSC1-ben [32]. Viszont a több exont érintő deletio, illetve a teljes géndeletio csak az esetek körülbelül 8\%-ában fordul elő [33].

A bemutatott négy esetben a TSC2 gén által kódolt tuberin fehérje különböző funkcionális doménjaiban ki-

1. táblázat |A bemutatott betegek genotípus-fenotípus összefüggései

\begin{tabular}{|c|c|c|c|c|c|}
\hline \multicolumn{2}{|l|}{ 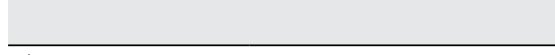 } & Beteg I & Beteg II & Beteg III & Beteg IV \\
\hline \multicolumn{2}{|l|}{ Életkor } & 2 & 10 & 40 & 35 \\
\hline \multicolumn{2}{|l|}{ Nem } & Férfi & Férfi & Nő & Nő \\
\hline \multicolumn{2}{|c|}{ Genetikai vizsgálat eredménye (MLPA) } & $\begin{array}{l}\text { TSC2: 1-35 } \\
\text { exondeletio }\end{array}$ & $\begin{array}{l}\text { TSC2: 17-41 } \\
\text { exondeletio }\end{array}$ & $\begin{array}{l}\text { TSC2: 5'UTR és } \\
\text { 1-2 exondeletio }\end{array}$ & $\begin{array}{l}\text { TSC2: } 5 \text { 'UTR és l-es } \\
\text { exon deletiója }\end{array}$ \\
\hline \multicolumn{2}{|c|}{ Családi anamnézis } & Negatív & Pozitív & Pozitív & Negatív \\
\hline \multirow[t]{4}{*}{ Bör } & Hypomelanoticus folt & + & + & - & + \\
\hline & Adenoma sebaceum & + & + & + & + \\
\hline & Köröm körüli fibroma & - & - & - & - \\
\hline & Shagreen folt & - & + & - & - \\
\hline \multirow[t]{6}{*}{ Idegrendszer } & SEN & - & - & - & + \\
\hline & SEGA & - & - & - & - \\
\hline & Corticalis tuber & + & + & + & + \\
\hline & Migrációs sáv & + & - & - & - \\
\hline & Epilepszia & + & - & - & + \\
\hline & Egyéb neurológiai tünet & $\begin{array}{l}\text { Generalizált } \\
\text { izomhypotonia, } \\
\text { megkésett mozgás- és } \\
\text { beszédfejlődés }\end{array}$ & $\begin{array}{l}\text { Dyslexia, } \\
\text { dysgraphia, } \\
\text { dyscalculia }\end{array}$ & - & $\begin{array}{l}\text { Elmaradt mentális } \\
\text { fejlődés, autisztikus } \\
\text { magatartás, időszakos } \\
\text { súlyos magatartászavar }\end{array}$ \\
\hline \multirow[t]{2}{*}{ Vese } & Angiomyolipoma & - & - & + & + \\
\hline & Vesecysta & - & + & - & - \\
\hline
\end{tabular}

MLPA = multiplex ligatiofüggő próba amplifikációja; SEGA = subependymalis óriássejtes astrocytoma; SEN = subependymalis nodus, TSC2 = tuberous sclerosis protein 2 gén 
alakult deletiók tehetők felelőssé az egyes betegek fenotípusos jegyeinek kialakulásáért. Elsőként két fiúgyermek esetét ismertettük, akik részben átfedő tünetekkel rendelkeztek (hipopigmentált foltok és corticalis tuberek). Az első esetében a családban TS nem volt ismert, míg a másodiknál több családtag is érintett volt. Az átfedő tünetek mellett a fiatalabb fiúgyermeknél állon elhelyezkedő fibroma, valamint epilepszia is megfigyelhetö volt, emellett neurológiailag generalizált izomhypotonia, valamint megkésett mozgás- és beszédfejlődés jellemezte. Esetében a TSC2 gén első 35 exonjának deletiója igazolódott, amely miatt a tuberin hamartinkötő régiója, az egyik transzkripcióaktiváló domén, a GAP-homológ domén első fele, valamint több aktin/proteinkináz B (Akt/ $\mathrm{PKB}$ ) függő foszforilációs hely is eltünt a képződött fehérjéről. A második fiúgyermeknél bőrgyógyászati tünetként shagreen folt, adenoma sebaceum, valamint a vese érintettsége is igazolódott. Epilepsziája nem volt, azonban dyslexia, dysgraphia és dyscalculia jellemezte. Tüneteinek hátterében a TSC2 gén 17-41 exonjainak deletióját mutattuk ki, amely miatt mindkét transzkripcióaktiváló domén, a teljes GAP-homológ domén, a kalmodulinkötő domén, valamint több Akt/PKB függő foszforilációs hely deletálódott.

A két nőbeteg, a fiúgyermekekhez hasonlóan, szintén részben átfedő tüneteket mutattak (adenoma sebaceum, corticalis tuberek és a veseérintettség). Hasonlóan az első két esethez, egyik beteg családi anamnézise pozitív, míg másik negatív volt. A 35 éves betegnél a fenti tünetekhez hipopigmentált foltok, epilepszia, mentális retardáció, autisztikus magatartás és súlyos magatartászavar társul. Mindkét betegnél az 5'UTR, valamint az l-es, 2-es exonok deletiója, illetve az 5'UTR és az 1. exon deletiója volt kimutatható. Esetükben a hamartinkötő régiót kódoló szakaszban bekövetkező deletio áll a tünetek hátterében, ami miatt a hamartin nem tud megfelelő módon kapcsolódni a tuberinhez. Annak ellenére, hogy a negyedik beteg esetében a deletio nagysága a legkisebb régiót érintette, mégis súlyosabb tünetekkel rendelkezett, mint a másik nőbeteg.

A 16-os kromoszómán található TSC2 szerkezetileg 41 exonból és a köztük lévő kisebb méretű intronokból áll [34]. A gén az 1784 aminosavból álló tuberint kódolja, amely szerkezetileg tartalmaz egy leucincipzárt a 3-as exonban, két kisméretû coiled-coiled régiót a 10-es és 26-os exonokban, két transzkripcióaktiváló domént a 29-es és 39-es exonokban, egy GAP-homológ domént a 34-38-as exonokban, valamint egy kalmodulinkötő domént a 40-es exonban. A hamartinkötő régió (1-11 exon) a fehérje N-terminálisán található, emellett több Akt/PKB függő foszforilációs helyet is tartalmaz [35]. A hamartin és tuberin az úgynevezett coiled-coiled régión keresztül kapcsolódnak egymáshoz, ezáltal képezve azt a fehérjekomplexet, amely különböző jelátviteli utakon keresztül szabályozza a sejtek homeosztázisát, oxigénszintjét, tápanyagfelvételét, a sejtnövekedést és a proliferációt [36]. Mivel a tuberin tartalmazza a GAP-ho- mológ domént, ezért a TSC2-mutációknak sokkal károsabb hatása lehet a komplex GAP aktivitására, emiatt okozhat nagyobb zavart az mTOR-jelátviteli útvonalban, ami ezáltal súlyosabb klinikai tünetekhez vezethet [37].

A TS bizonyos tüneteinek megjelenése életkor-, illetve nemfüggő [38]. Magzati korban és újszülötteknél leggyakoribb tünet a cardialis rhabdomyoma. Némileg hasonlóan - kora gyermekkorban - várható a SEGA kialakulása, a gyermekkor lezárulta után ennek a tünetnek a fellépésével már nem kell számolnunk [39].

A TS bőrtünetei a hypomelanoticus foltok, az angiofibromák, a shagreen foltok és az ungualis fibromák. A betegek 90\%-ánál fordulnak elő hipopigmentált foltok, amelyek már a nagyon korai életszakaszban megjelennek [12]. Szakirodalmi adatok alapján a TSC1/TSC2 érintettség kapcsán lényegében csekély különbség van a két gén közt (TSC1: 91\%, TSC2: 94\%) [26-28]. Viszont az adenoma sebaceum a TSC2-mutációt hordozó betegeknél jóval gyakrabban (76\%) fordul elö, mint TSC1génmutáció esetén $(55 \%)[26,28]$. A shagreen foltok a TS-betegek 20-30\%-ánál alakulnak ki, tipikusan a lumbalis területen. A bemutatott esetek közül három páciensnél hypomelanoticus foltok, adenoma sebaceum az idősebb fiúnál és a két nőbetegnél, míg shagreen folt csak az idősebb fiúgyermeknél látható.

A TS központi idegrendszeri tünetei is szerteágazóak lehetnek, sokszor súlyosabb tünettant alakítva ki. Ezek közül SEGA a TS-betegek 5-15\%-ánál alakul ki [40]. Az astrocytomák lassan növekvő jóindulatú tumorok, amelyek szövettanilag többféle sejttípusból épülnek fel [41, 42]. Corticalis tuberek lényegesen gyakrabban fordulnak elő és már az agykéreg fejlődése során kialakulnak [43, 44]. Az esetek 90\%-ában a TSC2-ben bekövetkező mutáció következményeként alakulnak ki, míg a TSCI az esetek 76\%-ában felelős a corticalis tuberek létrejöttéért $[27,28]$. Mind a négy bemutatott betegünk esetében a corticalis tuberek meglétét MR-vizsgálattal detektálták. Epilepsziás roham az esetek 75\%-ában alakul ki, amelyek 30-40\%-a terápiarezisztens [45]. A fiatalabb fiúgyermeknél, valamint szintén a fiatalabb nőbetegnél diagnosztizáltak epilepsziát. Mindkettejük esetében megfelelő gyógyszeres kezelés mellett a rohamok száma nagymértékben csökkent. A genetikai hátteret tekintve a TSC2génmutáció esetén gyakrabban (81\%) lép fel epilepszia, mint a TSC1-mutáció esetén (75\%) [45]. A rohamok általában a corticalis tuberekből indulnak ki, azonban a tuberek mellett elhelyezkedő corticalis területek is fontos szerepet játszanak a rohamok kialakulásában [42]. Corticalis tuber nélküli állatmodellen végzett vizsgálatok alapján ismert, hogy az epilepsziás roham kialakulásához elegendő csak az mTOR-jelátvitel hibás szabályozása is [46]. A kognitív és egyéb szociális zavarok szorosan öszszefüggenek az epilepsziás rohamok korai megjelenésével, valamint a rohamok számával. Emiatt a korai sebészeti beavatkozás csökkentheti a későbbi neurológiai tünetek megjelenését [47, 48]. Arra azonban egyelőre 
nem tudunk egyértelmű választ adni, hogy az epilepsziás rohamok következménye-e a TS-betegeknél gyakran kialakuló autizmus, valamint egyéb kognitív zavarok.

A TS-hez egyéb intellektuális, pszichés zavarok is társulhatnak. Ez utóbbiak megjelenhetnek szorongás, alvásprobléma, depresszió, agresszió vagy akár önkárosítás formájában is. Szintén nagyon gyakori az autizmus spektrumzavar és ADHD, amelyek a betegek 30-50\%ánál fordulnak elő [14]. Epidemiológiai adatok szerint a TS-betegek 50\%-ának átlagos az intellektusa, míg a másik $50 \%$-nál változó súlyossági fokú intellektuális zavar áll fenn [49]. Az iskoláskorú TS-betegek 30\%-ánál különböző tanulási részképességzavar észlelhető, még azon TS-betegek között is, akiknek az intellektusa átlagos. A két ismertetett fiúgyermeket beszédfejlődési, illetve tanulási részképességzavar, míg a fiatalabb nőbeteget mentális fejlődési elmaradás és autisztikus magatartás jellemzi. Az idősebb nőbetegnél ilyen jellegű tünetek nem ismertek, viszont az anyai leánytestvér egyik lánya mentális retardáció miatt intézetben él.

A TS renalis tünetei közül a betegek jelentős hányadánál alakul ki angiomyolipoma $(80 \%)$, illetve vesecysta (50\%), amelyek száma és mérete a kor előrehaladtával növekvő tendenciát mutat $[4,50]$. A két év körüli gyermekek 17\%-ánál, míg a 9-14 évesek 65\%-ánál fordul elő angiomyolipoma $[51,52]$. Vesetumorok hátterében szintén a TSC2 mutációi állnak gyakrabban (TSC1: 15\%, TSC2: 43\%) [31]. A betegek mintegy 2\%-ánál alakul ki polycystás vese szindróma, amelynek hátterében a TSC2 és a hozzá igen közel eső $P K D 1$ gén deletiói állnak [50]. Az itt tárgyalt esetek közül az elsőként bemutatott fiúgyermek kivételével minden beteg esetében jelentkeztek a betegségre jellemző jellegzetes renalis tünetek.

A négy magyar eset bemutatásával a nagyobb méretú géndeletiók relatív gyakori előfordulására kívánjuk felhívni a figyelmet. Véleményünk szerint közleményünk fontos információkkal járul hozzá a TS genotípus-fenotípus összefüggésekkel kapcsolatos ismereteinkhez, így segítve elő a betegek diagnosztizálását és ellátását.

Anyagi támogatás: A közlemény az NKFI PD115677 (témavezető: Dr. Kövesdi Erzsébet), K119540 (témavezető: Prof. Dr. Melegh Béla) és a GINOP-2.3.2-152016-00039 azonosítószámú projekt támogatásával valósult meg.

Szerzői munkamegosztás: B. J., K. E.: A molekuláris genetikai vizsgálatok elvégzése, értékelése. H. K., N. N., H. Á.: Betegvizsgálat. K. E., H. K., N. N., H. Á.: A kézirat megszövegezése. H. K., N. N., H. Á., M. B.: A kézirat áttekintése.

Érdekeltségek: A szerzőknek nincsenek érdekeltségeik.

\section{Irodalom}

[1] Gomez MR. History of the tuberous sclerosis complex. Brain Dev. 1995; 17(Suppl): 55-57.

[2] Crino PB, Nathanson KL, Henske EP. The tuberous sclerosis complex. N Engl J Med. 2006; 355: 1345-1356.

[3] Curatolo P, Bombardieri R, Jozwiak S. Tuberous sclerosis. Lancet $2008 ; 372$ : 657-668.

[4] Krueger DA, Northrup H, International Tuberous Sclerosis Complex Consensus Group.: Tuberous sclerosis complex surveillance and management: recommendations of the 2012 International Tuberous Sclerosis Complex Consensus Conference. Pediatr Neurol. 2013; 49: 255-265.

[5] Humphrey A, Higgins JN, Yates JR, et al. Monozygotic twins with tuberous sclerosis discordant for the severity of developmental deficits. Neurology 2004; 62: 795-798.

[6] Lyczkowski DA, Conant KD, Pulsifer MB, et al. Intrafamilial phenotypic variability in tuberous sclerosis complex. J Child Neurol. 2007; 22: 1348-1355.

[7] Földvári A, Szy I, Sándor J, et al. Diagnostic delay of rare diseases in Europe and in Hungary. [A ritka betegségek diagnosztikájának késedelme Európában és Magyarországon.] Orv Hetil. 2012; 153: 1185-1190. [Hungarian]

[8] Nellist M, Brouwer RW, Kockx CE, et al. Targeted Next Generation Sequencing reveals previously unidentified TSC1 and TSC2 mutations. BMC Med Genet. 2015; 16: 10.

[9] DiMario FJ Jr. Brain abnormalities in tuberous sclerosis complex. J Child Neurol. 2004; 19: 650-657.

[10] Shepherd CW, Gomez MR, Lie JT, et al. Causes of death in patients with tuberous sclerosis. Mayo Clin Proc. 1991; 66: 792796.

[11] Chu-Shore CJ, Major P, Camposano S, et al. The natural history of epilepsy in tuberous sclerosis complex. Epilepsia 2010; 51: 1236-1241.

[12] Curatolo P, Moavero R, de Vries PJ. Neurological and neuropsychiatric aspects of tuberous sclerosis complex. Lancet Neurol. 2015; 14: 733-745.

[13] D'Agati E, Moavero R, Cerminara C, et al. Attention-deficit hyperactivity disorder (ADHD) and tuberous sclerosis complex. J Child Neurol. 2009; 24: 1282-1287.

[14] Curatolo P, Napolioni V, Moavero R. Autism spectrum disorders in tuberous sclerosis: pathogenetic pathways and implications for treatment. J Child Neurol. 2010; 25: 873-880.

[15] de Vries PJ, Whittemore VH, Leclezio L, et al. Tuberous sclerosis associated neuropsychiatric disorders (TAND) and the TAND Checklist. Pediatr Neurol. 2015; 52: 25-35.

[16] Henske EP. Tuberous sclerosis and the kidney: from mesenchyme to epithelium, and beyond. Pediatr Nephrol. 2005; 20: 854-857.

[17] van Slegtenhorst M, de Hoogt R, Hermans C, et al. Identification of the tuberous sclerosis gene TSCl on chromosome $9 \mathrm{q} 34$. Science 1997; 277: 805-808.

[18] Kandt RS, Haines JL, Smith M, et al. Linkage of an important gene locus for tuberous sclerosis to a chromosome 16 marker for polycystic kidney disease. Nat Genet. 1992; 2: 37-41.

[19] van Slegtenhorst M, Nellist M, Nagelkerken B, et al. Interaction between hamartin and tuberin, the TSC1 and TSC2 gene products. Hum Mol Genet. 1998; 7: 1053-1057.

[20] Geoerger B, Blockus H. Everolimus for astrocytomas in tuberous sclerosis complex. Lancet 2013; 381: 95-96.

[21] Crino PB. mTOR: A pathogenic signaling pathway in developmental brain malformations. Trends Mol Med. 2011; 17: 734742 . 
[22] Ma XM, Blenis J. Molecular mechanisms of mTOR-mediated translational control. Nat Rev Mol Cell Biol. 2009; 10: 307318.

[23] Gai Z, Chu W, Deng W, et al. Structure of the TBC1D7-TSC1 complex reveals that TBC1D7 stabilizes dimerization of the TSCl C-terminal coiled coil region. J Mol Cell Biol. 2016; 8: $411-425$.

[24] Capo-Chichi JM, Tcherkezian J, Hamdan FF, et al. Disruption of TBC1D7, a subunit of the TSC1-TSC2 protein complex, in intellectual disability and megalencephaly. J Med Genet. 2013; 50: 740-744.

[25] Choi JE, Chae JH, Hwang YS, et al. Mutational analysis of TSC1 and TSC2 in Korean patients with tuberous sclerosis complex. Brain Dev. 2006; 28: 440-446.

[26] Dabora SL, Jozwiak S, Franz DN, et al. Mutational analysis in a cohort of 224 tuberous sclerosis patients indicates increased severity of TSC2, compared with TSC1, disease in multiple organs. Am J Hum Genet. 2001; 68: 64-80.

[27] Au KS, Williams AT, Roach ES, et al. Genotype/phenotype correlation in 325 individuals referred for a diagnosis of tuberous sclerosis complex in the United States. Genet Med. 2007; 9: $88-100$.

[28] Sancak O, Nellist M, Goedbloed M, et al. Mutational analysis of the TSC1 and TSC2 genes in a diagnostic setting: genotype phenotype correlations and comparison of diagnostic DNA techniques in Tuberous Sclerosis Complex. Eur J Hum Genet. 2005; 13: 731-741

[29] Jansen AC, Sancak O, D'Agostino MD, et al. Unusually mild tuberous sclerosis phenotype is associated with TSC2 R905Q mutation. Ann Neurol. 2006; 60: 528-539.

[30] Mayer K, Goedbloed M, van Zijl K, et al. Characterisation of a novel TSC2 missense mutation in the GAP related domain associated with minimal clinical manifestations of tuberous sclerosis. J Med Genet. 2004; 41: e64.

[31] Curatolo P, Moavero R, Roberto D, et al. Genotype/phenotype correlations in tuberous sclerosis complex. Semin Pediatr Neurol. 2015; 22: 259-273.

[32] Kozlowski P, Roberts P, Dabora S, et al. Identification of 54 large deletions/duplications in TSC1 and TSC2 using MLPA, and genotype-phenotype correlations. Hum Genet. 2007; 121: 389400.

[33] Kwiatkowski DJ. Genetics of tuberous sclerosis complex. WileyBlackwell, Weinheim, Germany, 2010.

[34] Maheshwar MM, Sandford R, Nellist M, et al. Comparative analysis and genomic structure of the tuberous sclerosis 2 (TSC2) gene in human and pufferfish. Hum Mol Genet. 1996; 5: 131137

[35] Rubinfeld B, Crosier WJ, Albert I, et al. Localization of the rap IGAP catalytic domain and sites of phosphorylation by mutational analysis. Mol Cell Biol. 1992; 12: 4634-4642.

[36] Kwiatkowski DJ. Rhebbing up mTOR: new insights on TSCl and TSC2, and the pathogenesis of tuberous sclerosis. Cancer Biol Ther. 2003; 2: 471-476.

[37] Zeng LH, Rensing NR, Zhang B, et al. Tsc2 gene inactivation causes a more severe epilepsy phenotype than Tscl inactivation in a mouse model of tuberous sclerosis complex. Hum Mol Gen et. $2011 ; 20$ : 445-454.

[38] Roach ES, Sparagana SP. Diagnosis of tuberous sclerosis com plex. J Child Neurol. 2004; 19: 643-649.

[39] Kotulska K, Borkowska J, Roszkowski M, et al. Surgical treatment of subependymal giant cell astrocytoma in tuberous sclerosis complex patients. Pediatr Neurol. 2014; 50: 307-312.

[40] Northrup H, Krueger DA, International Tuberous Sclerosis Complex Consensus Group.: Tuberous sclerosis complex diagnostic criteria update: recommendations of the 2012 International Tuberous Sclerosis Complex Consensus Conference. Pediatr Neurol. 2013; 49: 243-254.

[41] Sharma MC, Ralte AM, Gaekwad S, et al. Subependymal giant cell astrocytoma - a clinicopathological study of 23 cases with special emphasis on histogenesis. Pathol Oncol Res. 2004; 10: 219-224.

[42] Ruppe V, Dilsiz P, Reiss CS, et al. Developmental brain abnormalities in tuberous sclerosis complex: a comparative tissue analysis of cortical tubers and perituberal cortex. Epilepsia 2014; 55 : 539-550.

[43] Kwiatkowski DJ, Short MP. Tuberous sclerosis. Arch Dermatol. 1994; 130: 348-354.

[44] Wortmann SB, Reimer A, Creemers JW, et al. Prenatal diagnosis of cerebral lesions in tuberous sclerosis complex (TSC). Case report and review of the literature. Eur J Paediatr. Neurol. 2008; 12: $123-126$

[45] Jansen FE, van Huffelen AC, Algra A, et al. Epilepsy surgery in tuberous sclerosis: a systematic review. Epilepsia 2007; 48: 1477-1484.

[46] Zeng LH, Xu L, Gutmann DH, et al. Rapamycin prevents epilepsy in a mouse model of tuberous sclerosis complex. Ann Neurol. 2008; 63: 444-453.

[47] van Eeghen AM, Pulsifer MB, Merker VL, et al. Understanding relationships between autism, intelligence, and epilepsy: a crossdisorder approach. Dev Med Child Neurol. 2013; 55: 146-153.

[48] Buki A, Horvath Z, Kover F, et al. Occlusive hydrocephalus complicating tuberous sclerosis: report of two cases. Eur J Neurol. 1996; 3: 255-259.

[49] Joinson C, O'Callaghan FJ, Osborne JP, et al. Learning disability and epilepsy in an epidemiological sample of individuals with tuberous sclerosis complex. Psychol Med. 2003; 33: 335-344.

[50] Dixon BP, Hulbert JC, Bissler JJ. Tuberous sclerosis complex renal disease. Nephron Exp Nephrol. 2011; 118: e15-e20.

[51] Ewalt DH, Sheffield E, Sparagana SP, et al. Renal lesion growth in children with tuberous sclerosis complex. J Urol. 1998; 160: 141-145.

[52] Jozwiak S, Schwartz RA, Janniger CK, et al. Usefulness of diag nostic criteria of tuberous sclerosis complex in pediatric patients. J Child Neurol. 2000; 15: 652-659.

(Kövesdi Erzsébet dr., Pécs, Szigeti út 12., 7624 e-mail: kovesdi.erzsebet@pte.hu)

Az Orvosi Hetilap egyes számai megvásárolhatók a Mediprint Orvosi Könyvesboltban. Cím: Budapest V., Múzeum krt. 17. - Telefon: 317-4948 